Princeton

The Amphibian Ear

Ernest Glen Wever

This comprehensive work on the amphibian ear continues the examination of the nature and evolutionary development of the vertebrate ear begun in Ernest Glen Wever's earlier book, The Reptile Ear. Professor Wever studies the structure of the ear and its functioning as a receptor of sounds in all amphibian species (139) for which living representatives could be obtained. Structure is revealed by gross dissection methods and the microscopic examination of serial sec. tions; functioning is shown by general behavioral observations, particularly by the recording of electrical potentials produced by the auditory hair cells in response to sounds. $\$ 65.00$

Now Available in Paperback

\section{A Geological Miscellany}

Compiled by $G$. Y. Craig and E.J. Jones

This book is the finest piece of light reading in geology I have ever encountered!... I recommend A Geological Miscellany without reserva tion as a book that will bring both enlightenment and enjoyment."

-Ellis L. Yochelson, Geology $\$ 7.95$ Not for sale in the British Commonuealth, except Canada

\section{Colour}

Why the World Isn't Grey Hazel Rossolti

Why do pebbles look brighter when wet? Is there a "right" order in which to arrange a set of colored crayons? Why do some clothes change color when ironed? What are the colors you see when you press your eyes? To answer these and other questions, Hazel Rossotti uses scientific basics - matter, energy and eye structure - to discuss the colors of the natural world, the mechanism of color vision, and a range of color technology from ceramics to television. P: $\$ 8.95$. C: $\$ 32.50$

\section{At your bookstore or}

Princeton University Press 41 William Street, Princeton, NJ 08540

\section{Vision as a guide to action}

\section{Stuart Sutherland}

Visual Perception: Physiology,

Psychology and Ecology.

By Vicki Bruce and Patrick Green.

Lawrence Erlbaum: 1985. Pp.369. Hbk

£26.95, \$39.95; pbk £8.95, \$14.95.

IN THE edifice of visual psychology are many mansions. Most textbooks on the subject describe only the more conventional ones - colour vision, the visual illusions, visual after-effects, flicker, perspective, adaptation to wearing prisms and so on. In Visual Perception Vicki Bruce and Patrick Green ignore these hoary topics and present instead some of the exciting new developments that have taken place over the past 20 years. Their book is unusual: it provides almost the first elementary account of the use of computer simulation to further our understanding of vision (rightly relying mainly on the work of David Marr); it devotes many pages to vision in insects; and rather than concentrating on how visual sensations are produced or visual recognition achieved, it examines in some detail how vision can guide action.

For good measure, the authors throw in a useful and up-to-date account of the neurophysiology of the visual system including a description of $\mathrm{X}, \mathrm{Y}$ and $\mathrm{W}$ cells, of whose elusive properties nobody has yet succeeded in making sense. They write and argue clearly, and, as a supplement to existing textbooks or as an introduction to an advanced course on vision, the book will be invaluable; it could also be helpful to workers in other scientific disciplines who want to learn about recent developments in vision.

There are, however, a few faults, some of which arise because topics are not dealt with in sufficient breadth. For example, in describing how lines and edges are extracted from the image to achieve Marr's "primal sketch", Bruce and Green should have attempted to motivate the reader by. giving the reasons why this is, rather surprisingly, a very difficult thing to do; or again, they describe Marr and Nishihara's method of representing objects for the purpose of recognition without attempting to evaluate carefully how far it fits in with our current knowledge of the visual system; and their account of scene analysis is so condensed that the uninformed reader will have difficulty understanding what it is all about. Moreover, several of their diagrams are completely wrong (for example those on pages 76,131 and 264) and will puzzle or mislead the unsophisticated.

A more debatable feature is the attention paid to the ideas of J.J. Gibson, who believed that the dynamic visual image contained invariants that specified what was (0)1985 Nature Publishing Group present in the environment, and that these invariants were "picked up" directly by the eye with no underlying computational or inferential processes. The view is so silly that it is not worth taking seriously. Gibson was of course correct in believing that the starting point for what we see is the visual image, but who has ever doubted that? One example of an invariant is horizontal disparity between corresponding parts of the image on the left and the right eye: this disparity yields stereoscopic depth. But when we examine how disparity is actually detected and used, it turns out to be extremely complicated; despite much computational work on stereopsis over the past few years, there is still no theory that is completely adequate.

The same is true of most other invariants. Nor does one have to have read Gibson to understand that the time at which an object approaching at a constant speed will collide with someone's head can be derived from the expression $\mathrm{d} t / \mathrm{d} s$, where $s$ is the angle subtended at the eye by any two points on the object, and $t$ is the time of observation. As the authors point out, a more elaborate expression yields the hit-time for an object that is accelerating at a constant rate. Both the insect and the human brain almost certainly make use of formulae like these, the former for landing, the latter, among other things, for driving across busy intersections without collision. The use that organisms make of such invariants is fascinating and is spelt out in detail in the present book, but the formulations owe little or nothing to Gibson's ideas (which, after wasting much space on them, the authors are in any case eventually led to reject).

This misplaced emphasis on Gibson apart, Bruce and Green have written an interesting and pleasingly idiosyncratic book. If you want to know why sheep dogs can be trained to round up sheep, you will find the answer here, just as you will find answers to many other rarely discussed questions. And it is salutary to have a textbook that stresses that vision is a guide to action and not merely a device for providing a picture of the world in one's head.

Stuart Sutherland is Director of the Centre for Research on Perception and Cognition at the University of Sussex.

\section{New in paperback}

- Order out of Chaos: Man's New Dialogue with Nature by Ilya Prigogine and Isabelle Stengers. Publisher is Flamingo (an imprint of Fontana), price is $\mathbf{f 3 . 9 5}$. For review see Nature 310, 341 (1984).

- The Logic of Perception by Irvin Rock. Publisher is MIT Press, price is $\$ 11, £ 11.50$. For review see Nature 311, 283 (1984).

- The Left Hand of Creation: The Origin and Evolution of the Expanding Universe by John D. Barrow and Joseph Silk. Publisher is Counterpoint (Unwin Paperbacks), price is £3.95. For review see Nature 307, 394 (1984). 